\title{
Опыт и перспективы перехода оптико-электронного приборостроения на отечественную элементную базу
}

Е.В. Гаврилов, Д.В. Брунёв, В.М. Тимофеев

АО «НПК ПЕЛЕНГАТОР», Санкт-Петербург, 198095, Ивана Черных, 31-33

тел/факс: +7 (812) 578-53-28, эл.nочта: info@npk-pelengator.ru

DOI 10.34077/RCSP2021-24

В свете комплекса мер, принимаемых правительством РФ для обеспечения стратегической стабильности в целом и локализации значимых для государства наукоемких производств на территории страны, вопросам импортозамещения уделяется все большее внимание на всех уровнях принятия решений. В связи с этим, большинство предприятий военно-промышленного комплекса активно переориентируются на потребление новых отечественных разработок.

На примере ряда перспективных оптико-электронных систем авиационного и морского базирования, разрабатываемых и производимых АО «НПК ПЕЛЕНГАТОР», изложен опыт применения серийно выпускаемых и вновь разработанных компонентов и комплектующих отечественного производства.

Рассмотрен ряд проблемных вопросов, возникающих при работе с отечественными электронными, оптическими и оптико-электронными компонентами на всех этапах их жизненного цикла. Вынесен на обсуждение перечень перспективных направлений развития, востребованных в рассматриваемой области применения. 